\title{
Urgences
}

\section{S'asseoir tranquille...}

\section{Alain Blanchet}

Numéro 2, 3e trimestre 1981

URI : https://id.erudit.org/iderudit/025031ar

DOI : https://doi.org/10.7202/025031ar

Aller au sommaire du numéro

Éditeur(s)

Urgences

ISSN

0226-9554 (imprimé)

1927-3924 (numérique)

Découvrir la revue

Citer ce document

Blanchet, A. (1981). S'asseoir tranquille... Urgences, (2), 67-70.

https://doi.org/10.7202/025031ar

Ce document est protégé par la loi sur le droit d'auteur. L'utilisation des services d'Érudit (y compris la reproduction) est assujettie à sa politique d'utilisation que vous pouvez consulter en ligne.

https://apropos.erudit.org/fr/usagers/politique-dutilisation/
Cet article est diffusé et préservé par Érudit.

Érudit est un consortium interuniversitaire sans but lucratif composé de l’Université de Montréal, l'Université Laval et l'Université du Québec à Montréal. Il a pour mission la promotion et la valorisation de la recherche. https://www.erudit.org/fr/ 


\section{ALAIN BLANCHET}


S'asseoir tranquille

en sauvage

hurler à marée haute

s'accrocher au reflet de la lune

en caressant un rocher

grisé par la tendresse de la brise

sculpteur acharné des millénaires

infini cyclique

courbature de dépendance

maudite machination

d'une centrale d'hypothèque atomique

attelée à une calèche cosmique

qui figure sur le tableau électronique

quèq part dans le plus complet dictionnaire

des rédacteurs d'annonces classées

qui continuent eux aussi à croire qu'ils postulent

l'atroce vélocité de la salvatrice armée

en prenant le café à heure fixe

pendant que la terre se meurt 


\author{
Musique de rue \\ éclose fraîche ce matin \\ ivre douce libre \\ calmement répartie \\ entre les combats \\ les luttes innocentes \\ inutiles \\ brèche sur brèche \\ bouetteuse jeunesse \\ révoltée tendresse \\ éclose enfargée \\ dans la coquille sociale \\ dans la poubelle civilisée \\ grattée sur les cordes fragiles \\ de l'existence compromise
}

musique de rue

sale caractère

musique de rue dans son ventre

aux heures de pointe

infinie menue monnaie

dans l'étui de ma guitare

à la base de la pyramide

décadence show-bizz

buzzant sonnant faux

les réussites éphémères - les momies en transit 
Ces temps durs qui roulent sous les nuages du ciel paqueté ces usines qui nous guettent ces labyrinthes d'asphalte

ces matins qui puent

de la boucane jusque dans le coeur les nouvelles tristes à la radio les pluies acides de la météo

ces vies vagabondes

ces idées dans le beau temps

ces amours sans bon sens

ces longues danses sensuelles

ces temps doux qui roulent qui nous remettent à l'univers dans une fusion tendre enjôleuse 